\title{
An Evaluation of the Role of Oslo Accords in the West Bank Industry: an Economic Analysis of the 1994-2016 Period
}

Dr. Loai Abu Raida, Prof. Flávio Nunes, Dr. Wael Ennab 


\section{An Evaluation of the Role of Oslo Accords in the West Bank Industry: an Economic Analysis of the 1994-2016 Period}

\section{Abstract}

To understand the reality of the West Bank industry and several of its main obstacles, it is impossible to neglect the influence of past political events. In fact, the recent changes of the Palestinian geopolitical context have been causing direct impacts on the Palestinian economy in general and on the industrial sector in particular. One of the most relevant recent political events that influenced the evolution of the Palestinian society and economy is related to Oslo Accords signed in 1993, which has created the conditions for the establishment of the Palestinian Authority. The main objective of this article is precisely to evaluate how the new political conditions achieved with the creation of the Palestinian Authority have impacted the West Bank industrial development, in a sequence of three distinct phases: the first phase is from 1994 to 2000 matched with the beginning of the Palestinian Authority, and goes until the onset of the AlAqsa Intifada. The second phase is from 2000 to 2004 matched with the Al-Aqsa Intifada (or Second Intifada); and the third phase from 2004 until the present time, started with the stability achieved after Al-Aqsa Intifada. Methodologically, this study is based on a historical approach crossed with a statistical and cartographic analysis of data from the Palestinian Central Bureau of Statistics. The results demonstrate how erratic is the evolution of the West Bank industrial sector during this period, and that almost 25 years of the emergence of the Palestinian Authority, the weakness of the West Bank industrial sector still persist, in part as a consequence of external forces, namely all the impositions done by Israel to limit the sovereignty of the Palestinian Authority to control its territory and economy.

Key-words: Oslo Accords; Palestinian Authority; Economic Geography; Industry; Palestine; West Bank. 


\section{تقييم دور اتفاقات أوسلو على الصناعة في الضفة الغربية: تحليل اقتصادي للفترة 1994 - 2016}

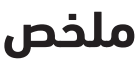

لفهم واقع صناعة الضفة الغربية وتفسير العديد من العقبات الرئيسة الناتجة عن تأثير الأحداث السياسية الماضية التي أدت إلى تغييرات في السياق الجئيل التيوسياسي الفلسطيني

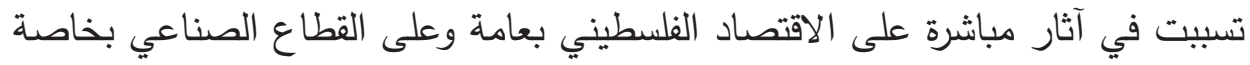

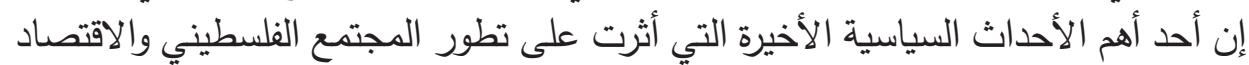

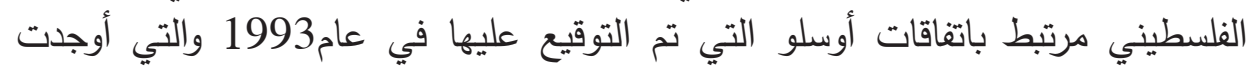

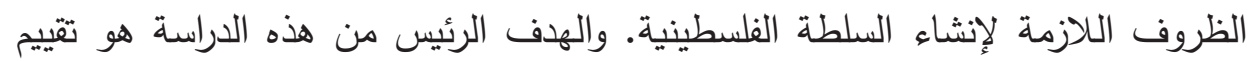

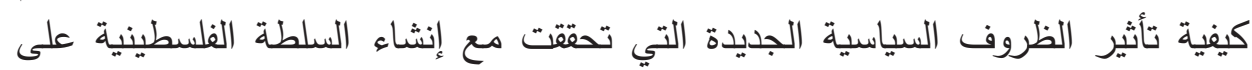
التتمية الصناعية للضفة الغربية، في ثلاث مراحل متميزة: المرحلة الأولى من بداية السلطة الثطاء

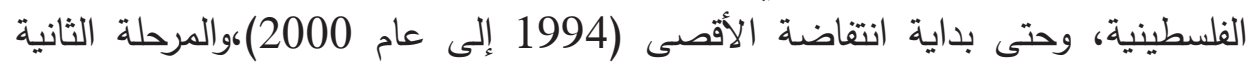

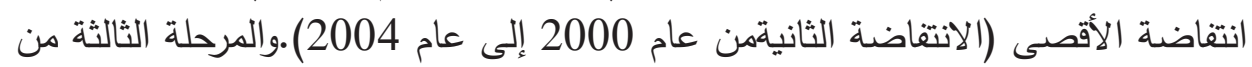
عام 2004 وحتى الوقت الحاضر ، دع الاستقرار الذي تحقق بعد انتفاضة الأقصى. من الناحية المنهجية، اعتمدت هذه الدراسة على المنهج التاريخي و المنهج الإحصائي

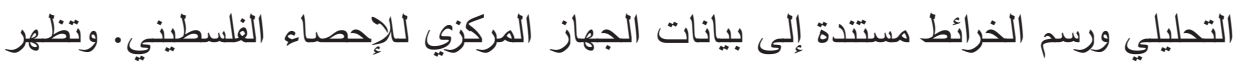

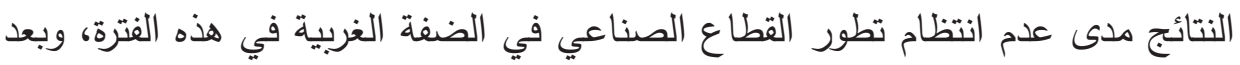

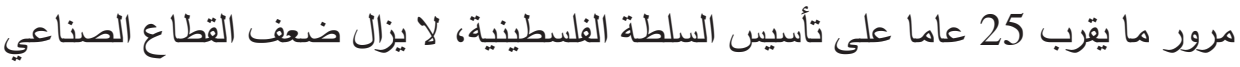

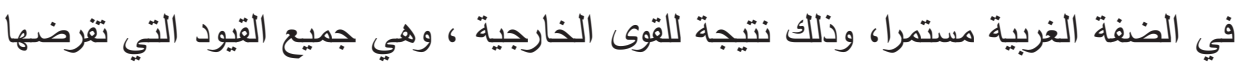
إسرائيل للحد من سيادة السلطة الفلسطينية على أراضيها والفيه واقتصادها.

الكلمات المفتاحية: اتفاقات أوسلو؛ السلطة الفلسطينية؛ الجغرافيا الاقتصادية؛ صناعة؛

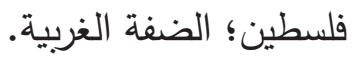




\section{Introduction}

The signing of the Oslo Accords, a peace-treaty promoted by the United Nations in 1993 between the PLO (Palestine Liberation Organization) and Israel, led to the establishment of the Palestinian Authority in 1994, which received administrative tasks and responsibilities on limited geographical regions of the Palestinian territories occupied in 1967(Naqib, 2003; Meckla, 2014). At that time, it was established the foundations for the beginning of a new development stage of Palestinian society and economy. Nevertheless, following Oslo Accords, the Palestinian economy in general and the industrial sector in particular are still operating under difficult conditions, due to the Israeli decision of limiting the responsibilities of the Palestinian Authority in the control its economy (Aburaida, 2017). Even so, the Palestinian Authority has been doing, since 1994, some efforts to help the development of its industrial firms, by providing supporting institutions (Palestinian Ministry of National Economy - MNE; Palestinian Investment Promotion Agency - PIPA; Palestine Standards Institute - PSI; Palestinian Industrial Estates and Free Zones Authority - PIEFZA) and better conditions to perform their missions, through the establishment of several international trade agreements: Free Trade Agreement with Egypt -signed in 1994; Declaration of Free Trade between the USA and West Bank and Gaza Strip - signed in 1996; Adhesion to the Greater Arab Free Trade Area - signed in 1997; Interim Agreement on Trade and Cooperation with the European Union - signed in 1997; Free Trade Agreement with Jordan - signed in 1998; Interim Agreement with EFTA States - signed in 1998; Agreement on Commercial Cooperation between the Palestine Liberation Organization and Russia - signed in 1998; Framework on Economic Cooperation and Trade between Palestine and Canada - signed in 1999; Interim Agreement on Trade with Turkey signed in 2004; Agadir Agreement - signed in 2004; Free Trade Agreement with MERCOSUR - signed in 2011 (PALTRADE, 2016). Despite all efforts to establish these international trade agreements, Israel is in full control over Palestinian trade movements as importing and exporting products to and 
from the Palestinian market is done through Israeli ports, or by borders controlled by Israel, forcing those exchanged goods to be subjected to Israeli standards and regulations. This circumstance causes impediments on movement of goods and discrimination against Palestinian products in the Israeli ports, resulting in a minimal utilization of these trade agreements.

Moreover, to promote the Palestinian industry development, the Palestinian Authority has been working as well on empowering both the role of general and sectorial industrial associations (Palestinian Federation of Industries PFI; Palestine Trade Centre - PalTrade; Federation of Palestinian Chambers of Commerce, Industry and Agriculture - FPCCIA; Palestinian Businessmen's Association), and also working on the improvement of the business legal framework. In this regard, the Palestinian Authority issued a number of acts and laws to regulate investments and ease the movement of capitals in order to attract industrial investments, such as the Investment Promotion Law in 1998. The Investment Promotion Law regulates the process of granting incentives for investments in order to attract new industrial investments (PIPA, 1998), despite being target towards supporting the relatively large investments. As well as other laws, as the one that aims at providing advanced services to local and foreign investors to facilitate the communication process between the private sector and government, by the 'Palestinian Investment Promotion Agency'.

Furthermore, the Palestinian Authority has managed to rate four industrial zones (created with the help of foreign donations) as priority zones for industrial development: the Jenin industrial zone planned with the help of the German government (from KFW - German government owned development bank); the Tarqumia industrial zone planned with the help of the Turkish government; the Bethlehem industrial zone planned with the help of the French government; and the special Jericho agricultural zone to help the agro-food industry and planned with the help of the Japanese government (PFI-USAID, 2009). To facilitate the investment in those zones, it has been recently launched the division 'One Stop Service - OSS', dedicated to offer 
integrated support for investors to start their businesses in industrial areas, providing them simple, fast, precise, and accountable licensing and nonlicensing services (PIEFZA, 2014; Salah, 2015).However, with the exception of the Jericho Agro-Industrial Park, there is still not much progress on the ground on the application of these investments, as two of these four industrial zones are still just proposals (PFI-USAID, 2009). The Jericho AgroIndustrial Park aims at organizing the Palestinian agro-industrial sector in Jericho and Jordan valley. It was planned with the help of the Japanese government initiative 'The Corridor for Peace and Prosperity' and it aims at generating 5000 direct or indirect jobs. Until 2015 it received 26 industrial units with a total employment of 583 workers (PIEFZA, 2015).

Despite all these efforts exerted for the advancement of the Palestinian industrial sector, the progress is still humble, insufficient and the industrial sector not achieved the desired modernization level. This paper intends to evaluate how the new political conditions achieved with the Oslo Accords have impacted the West Bank industrial development. After a brief presentation of the West Bank economic geography evolution during this period (19942016), it will be discussed how the recent geopolitical evolution of Palestine has influenced the West Bank industrial development in a sequence of three distinct phases: the first phase from 1994 to 2000 match with the beginning of the Palestinian Authority and goes until the onset of the Al-Aqsa Intifada; the second phase from 2000 to 2004 match with the Al-Aqsa Intifada (or Second Intifada); and the third phase from 2004 until the present time, started with the stability achieved after the Al-Aqsa Intifada. 


\section{Problem of the study}

Despite the Oslo Accords of 1993 have created the conditions for the establishment of the Palestinian Authority (Naqib, 2003), the Israeli occupation is still a reality in all West Bank, even in those territories where the Palestinian Authority was supposed to have a fully administrative control (PCHR, 2016). This external influence is responsible for several obstacles to the West Bank industrial development and growth. Under the framework of this continuous occupation, Israel turned the West Bank into both a source of cheap workforce to Israel economy and a successful trade arena for its products (Aburaida, 2017). In addition, Israel imposed major constraints on Palestinian economic activities, specifically the industrial ones, which are still nowadays retracting its growth and competitiveness (Epstein, 2002). In fact, the data presented by MAS (2013) in a study entitled "The Palestinian Economy After 20 years of Oslo Accords", indicated that the share of the industrial sector contribution to the Palestinian GDP declined from $22.3 \%$ in 1994 to become less than $12 \%$ at the end of 2012. In opposition, the share of services sector rose from $25 \%$ in 1994 to $58 \%$ at the end of 2012. According to Rantisi (2016), this evolution was responsible for a huge increase in the Palestinian trade deficit, as in 2014 the Palestinians exports to international markets amounted to 943 million dollars and Palestinian imports amounted to around 5.7 billion dollars. All these figures demonstrate the difficulties currently faced by a shrinking industrial sector, that has been progressively losing its relevance in the Palestinian society.

The low dynamic of this industrial sector, mainly composed by traditional and small-sized businesses, is also proven by its restriction to the local market and its failure to export and to attract foreign direct investment (ElJafari, 2016). Meanwhile, the data from the Palestinian labor force surveys (PCBS, 1996, 2015-a), indicates the increase in the unemployment rate from $13.9 \%$ in 1995 to $25.9 \%$ in 2015 , and in this context it has been advocated that the industrial sector development could contribute to solve this social problem, as the Palestinian industrial sector is working at $50 \%$ of production 
capacity and in a scenario of increasing its production capacity to $70 \%$, that would create about 40 thousand new jobs (Attiyani, 2016).

\section{Research Questions}

To understand the reality of the West Bank industry and several of its main obstacles, it is impossible to neglect the influence of past political events, as recent changes of the Palestinian geopolitical context have been causing direct impacts on the Palestinian economy in general and on the industrial sector in particular. Under this framework this study has two main research questions:

- How do the new political conditions (Oslo Accords) influence the recent evolution of the West Bank economic geography during the 19942016period?

- How does the recent geopolitical evolution of Palestine influence the West Bank industrial development in the same period: 19942016-?

\section{Methodological Approach}

Methodologically, this study is based in a statistic and cartographic analysis, mostly grounded on data published by the Palestinian Central Bureau of Statistics, that carried out a series of industrial surveys in the West Bank since the establishment of the Palestinian Authority. Unfortunately there are some limitations in the use of these databases, which results from a clear inconsistency in the official surveys used over this period. Therefore, the following analysis is dependent on the available indicators. For instance, the total number of employees is not available by economic branches for each West Bank Governorates, which avoid any attempt of calculating the economic specialization index for the West Bank Governorates. Besides, the indicators are not available for all variables for the same years, so the comparative analysis presented in this study is not always for the same exact period.Moreover, this research privileges an historical approach, as it is not possible to understand and the current challenges faced nowadays by the 
industry in the West Bank, without taking into consideration the influence of some past events that occurred during last decades. Historical events which have had tremendous implications on the Palestinian geopolitical evolution, and consequently in the way that nowadays industrial activities based on the West Bank work and the constraints that affect their performance and competitiveness.

\section{The recent evolution of the West Bank economic geography:}

\section{4: 2016}

According to the statistical data published by the Palestinian Central Bureau of Statistics, after 1994,the Palestinian economy has become a majority based on the services sector, as it represented in 2015 almost 23/ of all Palestine employment (Figure 1).

Figure 1. Evolution of West Bank employment by economic activity 19962015

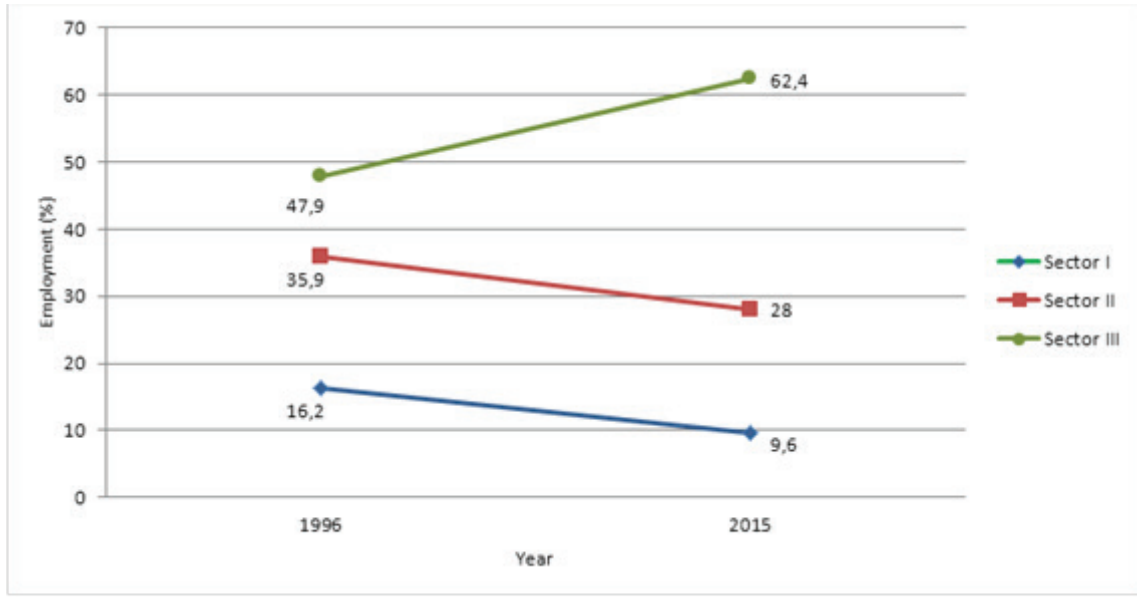

Source: data from PCBS $(1997,2016)$

The figures about the evolution of employment by economic activity, between 1996 and 2015, indicate that after the signing of the Oslo Accords, the Palestinian economy has clearly become more based at the service sectors, at the expense of a transference of workers from the other two productive 
sectors: the secondary activity sector (industry, energy production and construction) has passed from 36\% of all the Palestinian employment in 1996 to $28 \%$ in 2015; and the primary sector (agriculture, animal production and forestry activities) has evolved from $16,2 \%$ of all the Palestinian employment in 1996 to $9,6 \%$ in 2015 . It is true that the tertiarization of the economy is a global and desired/inevitable trend (UN-DESA, 2013), that expresses the service sector expansion as a consequence of the personal and household consumption increase, as well as driven by economic activities services consumption, helping them to get more added value in their business. However, in Palestine, the problem of this economic evolution is that the reduce of employment in those two sectors (primary and secondary sectors) is not so related with the effects of the mechanization/informatization of their productive processes, or with the effects of evolving to low labour intensity and high tech activities with more added value (both trends releasing workers for other emergent activities in the tertiary sector). In fact this local trend is a more worrying consequence from the continuous confiscation of Palestinian land by Israel, particularly during First and Second Intifada, and also from a problematic loss of local competitiveness, preventing the opening of new businesses and in some cases forcing the bankruptcy and the closure of many of already existing companies (Aburaida, 2017).

Geographically, this tertiarization trend of Palestinian economy is affecting almost of all West Bank territory. Analyzing the changes that have occurred in the distribution of workers between 1997 and 2016, there is evidence of a diversity decrease in the economic specialization of West Bank governorates (Figure 2). In 1997, there were governorates with an employment specialization in activities from each of the 3 economic sectors (primary, secondary and tertiary), particularly in four distinct economic branches (4 governorates with more employees in the services activities, 2 governorates were the majority of workers were employed in the primary sector activities, 1 governorate specialized in the economic branch related with mining, quarrying and manufacturing activities, and 1 
with more employment in the commerce, hotels and restaurants activities). Two decades later, in 2016, almost all governorates have their higher proportion of employment in the services activities, with the only exception of Jerusalem governorate where the majority of their workers are employed by companies related with construction activities.

The expansion of construction activities in Jerusalem Governorate is a direct result of the Judaization of Jerusalem. The first Israeli colony was built inside the Old City of Jerusalem immediately after the 1967 Six Days War, and during the years of occupation Israeli colonies have greatly expanded within the borders of the Jerusalem Municipality and the surrounding areas. This Israeli policy has continued in the Palestinian Authority period and it was specially intensified after the Second Intifada, which has promoted the local construction activities. Nowadays, there are a total of 19 Israeli colonies in the Jerusalem Governorate (18 within the municipal boundaries of Jerusalem) and Israel still intends to expand these colonies (ARIJ, 2015).

Figure 2. Employment specialization by West Bank governorates 19962015-

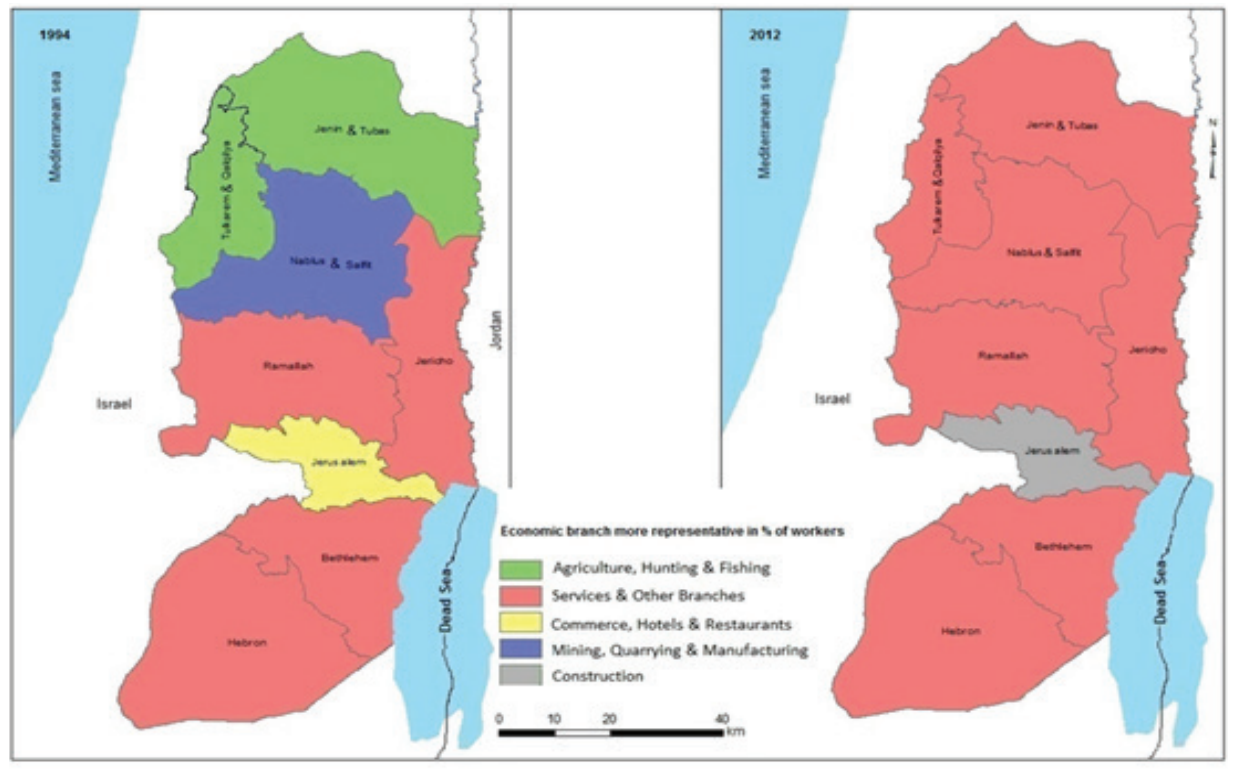

Source: author's elaboration with data from PCBS $(1997,2016)$ 
The more relevant changes in the economic geography of West Bank were especially felt in the North, were 2 governorates (Jenin \& Tubas and Tulkarem\&Qalqiliya) have evolved directly from primary sector activities to the tertiary sector, between 1996 and 2015. However, this was not a consequence of the dynamism of the services activities, but above all a result of the agriculture weakening trend, for reasons related with political options taken by Israel in the previous period of occupation. It is also relevant to observe that in 1996 there was one governorate in the North (Nablus \&Salfit) that was specialized in the 'mining, and quarrying and manufacturing' activities, and it has lost this specialization in the last 20 years to the services activities. Other loss of diversity in the economic geography of West Bank happened in Jerusalem governorate, that in 1996 had the majority of their jobs related with its worldwide religious tourism advantage (most of their jobs were in services related with commerce, hotels and restaurants), but surprisingly it has lost the ability to explore this unique advantage over the last two decades.

In order to get a deeper analysis of the evolution of the West Bank economic geography during this period, it is possible to focus our analysis by each economic branch (Table 1). The agriculture sector has witnessed a significant decline in all governorates during the period of 1996-2015, except for Bethlehem \& Jericho which has witnessed an increase in the proportion of workers in the agricultural sector, as its employment increased from $14 \%$ to $18 \%$. This is in part a consequence of the Jericho Agro-Industrial Park, which has intensified local agriculture production to supply these new investments in the agro-food industry. Besides, it also comes as a result of an increased demand by the domestic market for agricultural products, as well as some exportations, especially after the trade agreements between the Palestinian Authority and Israel and the Arab countries (Al-Sayeh, 2015). 
Table 1. Evolution of the employment proportion (\%) by each West Bank governorate and economic branch, between 1996 and 2015

\begin{tabular}{|c|c|c|c|c|c|c|c|c|}
\hline & & 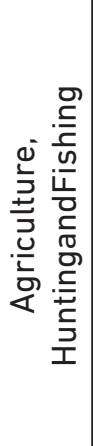 & 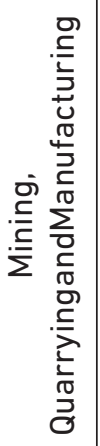 & 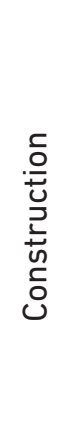 & 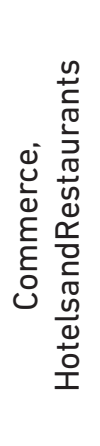 & 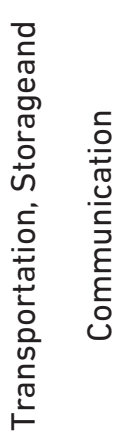 & 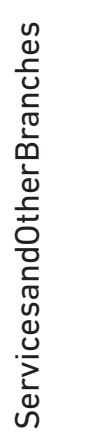 & $\begin{array}{l}\vec{\pi} \\
\stackrel{0}{0}\end{array}$ \\
\hline \multirow[t]{2}{*}{ Hebron } & 1996 & 14.4 & 20.9 & 20.2 & 18.2 & 5.3 & 21 & $100 \%$ \\
\hline & 2015 & 8.7 & 18.7 & 22.4 & 22.1 & 5.3 & 22.8 & $100 \%$ \\
\hline \multirow{2}{*}{$\begin{array}{l}\text { Bethlehemand } \\
\text { Jericho }\end{array}$} & 1996 & 14.3 & 18.3 & 18.8 & 16.3 & 3.6 & 28.7 & $100 \%$ \\
\hline & 2015 & 18.0 & 13.5 & 12.8 & 18.8 & 3.6 & 33.3 & $100 \%$ \\
\hline \multirow[t]{2}{*}{ Jerusalem } & 1996 & 0.7 & 14.8 & 17.3 & 29.9 & 10.1 & 27.2 & $100 \%$ \\
\hline & 2015 & 0.8 & 12.4 & 32.0 & 24.5 & 6.7 & 23.6 & $100 \%$ \\
\hline \multirow[t]{2}{*}{ Ramallah } & 1996 & 10.2 & 16.6 & 26.4 & 15.4 & 3.9 & 27.5 & $100 \%$ \\
\hline & 2015 & 4.8 & 12.6 & 18.3 & 18.9 & 5.2 & 40.2 & $100 \%$ \\
\hline \multirow{2}{*}{$\begin{array}{c}\text { Nablus and } \\
\text { Salfit }\end{array}$} & 1996 & 13.5 & 24.3 & 13.1 & 20.2 & 4.7 & 24.2 & $100 \%$ \\
\hline & 2015 & 5.5 & 19.3 & 21.4 & 17.3 & 5.5 & 31.0 & $100 \%$ \\
\hline \multirow{2}{*}{$\begin{array}{c}\text { Tulkaremand } \\
\text { Qalqiliya }\end{array}$} & 1996 & 26.2 & 15.4 & 16.8 & 15 & 4.5 & 22.1 & $100 \%$ \\
\hline & 2015 & 13.2 & 16.5 & 19.0 & 19.3 & 4.8 & 27.2 & $100 \%$ \\
\hline \multirow{2}{*}{$\begin{array}{l}\text { Jenimand } \\
\text { Tubas }\end{array}$} & 1996 & 31.6 & 9.9 & 16.2 & 16.6 & 4.1 & 21.6 & $100 \%$ \\
\hline & 2015 & 26.1 & 9.8 & 14 & 17.5 & 4.2 & 28.4 & $100 \%$ \\
\hline
\end{tabular}

The proportion of the Governorate employment in this economic branch has increased

The proportion of the Governorate employment in this economic branch has decreased

The proportion of the Governorate employment in this economic branch was stable

Source: data from PCBS $(1997,2016)$ 
The 'mining, quarying and manufacturing' activities have witnessed a decline in almost all of the governorates, with the only exception of Qalqiliya and Tulkarem where the employment rate had just a slight increase from $15.4 \%$ to $16.5 \%$. It is important to highlight that Nablus \& Salfit remain in 2015 (as it was in 1996), the West Bank governorate where we can find a higher proportion of employment in this economic branch (almost 15/ of its employment). In second position comes Hebron with 18,7\%. Jenin \& Tubas is the least relevant in these activities, employing less than $10 \%$ of all its workers, and this proportion has been stable over the last two decades.

The construction sector employment has faced a transition between two governorates. In 1996 Ramallah \& Al-Bireha concentrated more on construction workers than any other West Bank governorate $(26,4 \%$ of total employment), as a consequence of the concentration in this governorate, after Oslo Agreement, of the majority of public services related with the creation of the Palestinian National Authority. However, in 2015, it has lost that specialization in favor of Jerusalem governorate, where almost $132 \%) 3 /$ ) of their workers are related with construction activities, most of them involved in the construction of the new Israeli colonies created in Jerusalem governorate after the Second Intifada (the wages in construction activities in Jerusalem governorate are higher than in any other West Bank governorate). The increase in the proportion of the construction employment in Jerusalem had happened simultaneously with a decrease in all other economic branches in this governorate, including the tertiary activities.

The employment in commerce, hotels and restaurants has increased in most of the governorates, except for Nablus, Salfit and Jerusalem. The transport, storage and communication activities have a minor relevance in all West Bank governorates, the one where is more present is in the Jerusalem governorate employing only $6,7 \%$ of total workers, and this rate decreased from 1996 where it was above $10 \%$. The other services (public services, services to firms, real estate activities and financial activities) have witnessed the most dramatic changes with the biggest increase in the 
employment rate at the expense of the other economic branches. Almost all of the governorates have experienced an increase in the proportion of workers in this sector, except for Jerusalem which have actually witnessed a decline. Ramallah \& Al-Bireh are the more important governorate in these activities (more than $40 \%$ of Ramallah employment is in these services). Ramallah became the administrative capital of the Palestinian Authority, which led to the concentration of all official governmental institutions and the big health and educational institutions, as well as the main private sector institutions related with finance, insurance, consultancy and other business services (Abu Hawa, 2014).

Focusing exclusively in the industrial sector and regarding the evolution of the industrial establishments between 1994 and 2012, we can notice that the number of manufacturing activities has increased from 7185 in 1994 to 12657 in 2012, i.e. around 5472 new industrial units have been established during this period with an average annual growth rate of $3,2 \%$. However, it will be explained in the following sections this increase trend was not regular during this period.

A global analysis of the industrial establishments evolution, shows that Hebron in the south came as the most dynamic governorate in terms of the creation of manufacturing activities between 1994 and 2012 (PCBS, 1996, 2013-a), with 1415 new units, followed in the north by Jenin \& Tubas (more 953 units) and Nablus \& Salfit (more 789 units). Tulkarm and Qalqiliya (near the border with Israel) and Jericho (near the border with Jordan) where only 41 new units were created, where the West Bank governorates less dynamics in the creation of new manufacturing activities.

Analyzing the manufacturing activity is more relevant in each governorate in terms of the total number of firms (Figure 3 ). It is visible a relevant change between 1994, prior to the creation of the Palestinian Authority, and 2012. When the Palestinian Authority was created in 1994, it was visible a more diversified pattern, with six manufacturing activities dominating the industrial sector of West Bank governorates. From 1994 to 2012 it 
was witnessed a concentration of the West Bank governorates in just 3 manufacturing activities (which is a sign that suggests an evolution for an industrial profile less diversified): 'metal products manufacturing, except machinery and equipment'; 'wood products and furniture manufacturing'; and "foods and beverages manufacturing'.

Figure 3. Evolution of the main manufacturing activity by governorate in terms of the number of firms: 1994 and 2012

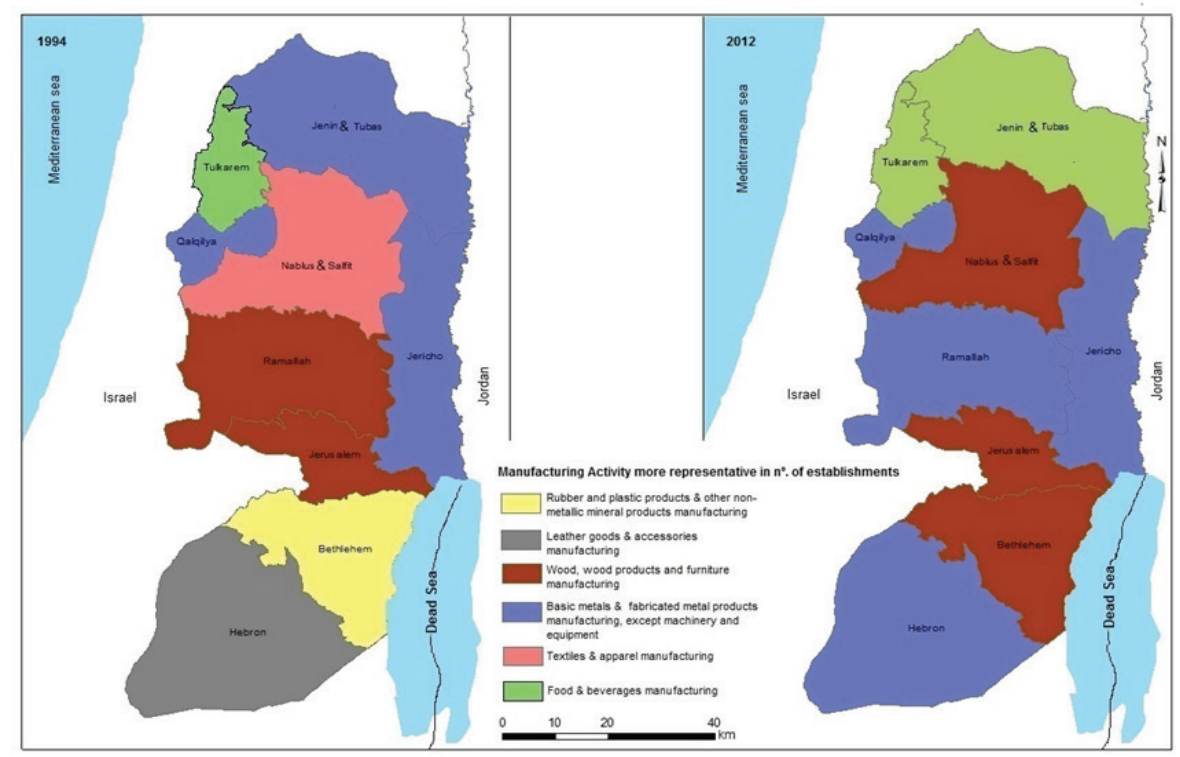

Source: data from PCBS (1996, 2013-a)

'Metal products manufacturing, except machinery and equipment' is the activity that dominates in 2012 the industrial sector of more governorates -four-: in Qalqiliya and Jericho that was already the reality in 1994, but in case of Hebron it has changed its specialization from 'leather goods \& accessories manufacturing' and in Ramallah it has changed from 'wood products and furniture manufacturing'.'Wood products and furniture manufacturing' dominates in 2012 the industrial sector of three governorates: in Jerusalem that was already the reality in 1994, but in case of Bethlahem it has changed its specialization from 'rubber and plastic products \& other non metallic 
mineral products manufacturing' and in Nablus \&Salfit it has changed from 'textiles \&apparel manufacturing'. And finally 'Foods and beverages manufacturing' dominates in 2012 the industrial sector of two governorates: in Tulkarm that was already the reality in 1994, but in the case of Jenin \& Tubas, it has changed its specialization from 'metal products manufacturing, except machinery and equipment'.

\section{The recent geopolitical evolution and its impact in the West Bank} industrial development.

The West Bank manufacturing activities have increased from 7185 in 1994 to 12657 in 2012 . However this increase trend was not regular over these years. So, on the next pages it will be presented the evolution of the West Bank industrial activities during the Palestinian Authority period, in a sequence of three distinct phases: the first is from 1994 to 2000 matching with the beginning of the Palestinian Authority and goes until the onset of the Al-Aqsa Intifada; the second is from 2000 to 2004 match with the AlAqsa Intifada (or Second Intifada); and the third phase begun in 2005 and started with the stability achieved after the Al-Aqsa Intifada.

\subsection{The first phase: 19942000 - (Oslo Accords - beginning of Al-Aqsa Intifada)}

In the beginning of this phase the West Bank industrial structure was dominated by the metal products manufacturing (except machinery and equipments), the food industry, and the clothing and textile industry, who have acquired the highest percentages in the total number of West Bank manufacturing activities. In 1994 their percentages reached 21,8\%, 16,1\% and $15,8 \%$ respectively (PCBS, 1996). These industries were concentrated mostly in Nablus (Figure 4), where the number of factories was 2063 in 1994, representing about $28,6 \%$ of total industrial activities in the West Bank (it is important to highlight that Nablus governorate in that period administratively comprised Salfit). 
Figure 4. The geographical distribution of manufacturing industries in 1994

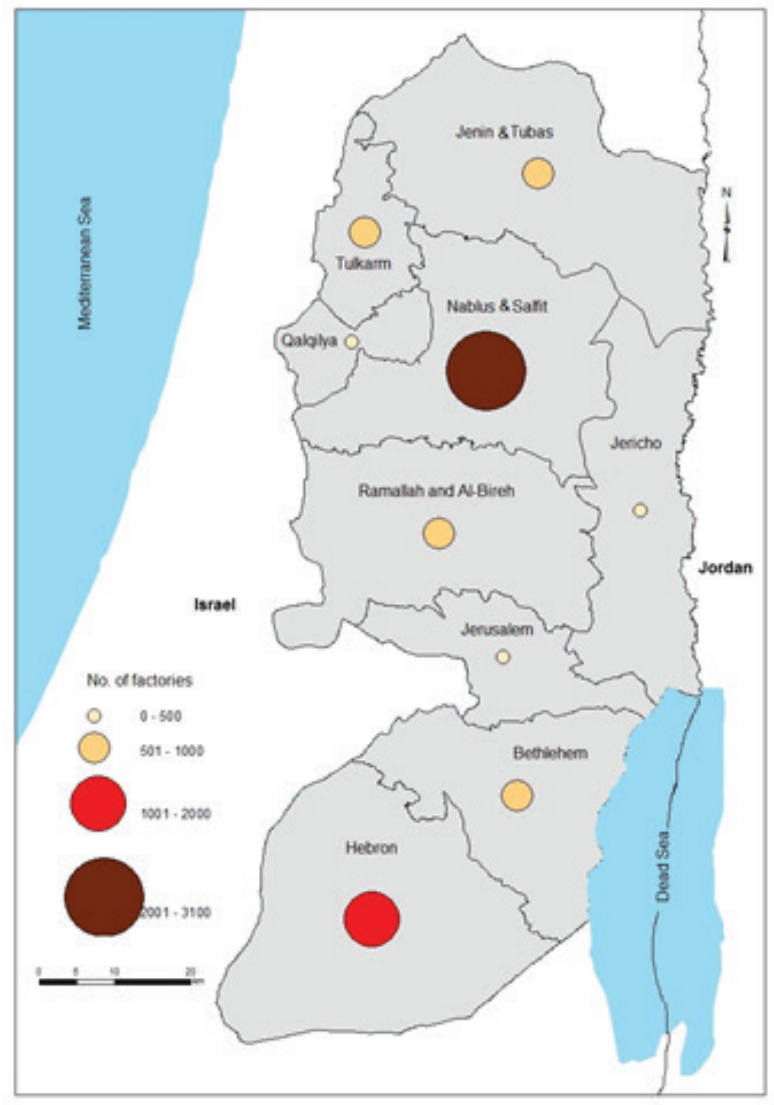

Source: data from PCBS (1996)

Regarding the geographical distribution of industrial firms in the West Bank; in the beginning of the Palestinian Authority period, Hebron governorate comes in second place, where the number of factories reached 1618 factories and accounted for about $22.5 \%$ of the total number of factories in the West Bank. While the less industrialized governorates were Jerusalem (6,5\%), Qalqilya (3,1\%), and specially Jericho where the industrial establishments did not exceed $0,9 \%$.

From 1994 to 2000, the number of industrial establishments evolved from 7185 to 11509 (an increase of 60\%). The industrial sector has witnessed 
a rapid development since the establishment of the Palestinian Authority after the signing of the Oslo Accord. From the beginning of this self-ruled period, the Palestinian Authority has prepared several plans and programs aiming at the development of the Palestinian economic activity, including the activities of the industrial sector, in order to achieve high growth rates, and contribute to the overall development process. Palestinian Authority used the money of the Palestinian Investment Fund to the development of the industrial sector, namely providing financial guarantees for banks to be able to provide the necessary funds to small and medium industrial projects. Besides, it has started to establish several international trade agreements to encourage the Palestinian goods exportations, and it has launched the Investment Promotion Law to facilitate industrial investors projects. As a result of all those policies, the industrial sector's contribution to GDP(gross domestic product) increased from $8 \%$ in 1993 to $16.8 \%$ in 1998 , so the sector has achieved an increase rate of $50 \%$ during the course of five years (Hazboun\&Bahiri, 1994).

Despite the positive evolution in the industrial sector contribution to the West Bank GDP over this first phase of the Palestinian Authority, the majority of studies and reports have shown the constant presence of structural defects, and the weakness of the overall performance of this economic sector (Makhol\&Atyani, 2001; Abdul-Khaliq, 2004; Nasrallah\&Awad, 2004; Surani, 2006; UNCTAD, 2011; World Bank, 2013). In fact, the ratio of external industrial sales declined in the West Bank from 20\% in 1997 to $18 \%$ in 1999 , which indicates the high dependence of the local market and the difficulties to conquest external markets (MAS, 2001). This evolution is mostly a consequence of the 'Paris Economic Protocol' signed in 1994, which is an economic agreement that was part of Oslo Accords, which is in view of some Palestinian economists the big mistake made by the Palestine Liberation Organization against the interest of the Palestinian economy, and accepted by the Palestinian Authority that did not demand its revision or negotiation on the following years (MAS, 2012; Shu'aybi, 2013). Unfair competition affecting 
West Bank goods is a main obstacle to local firms, which was mainly caused by the Paris Economic Protocol that gave the opportunity for the Israeli products to invade the Palestinian market at the same time, it prevents many of the Palestinian products from entering the Israeli market. Besides, the Paris Economic Protocol increased raw material prices with higher customs on raw materials imported from Israel and from other countries, which had a negative impact on the local industrial competitiveness. To deal with this loss of Palestinian products competitiveness in foreign markets, the Palestinian Authority did not have the needed funds, and mostly because Israel worked during its occupation on reducing the Palestinian financial resources in an organized and programmed manner, which was done through three basic channels; (1) through charging VAT (value added tax) on Palestinian imports from other countries, (2) the social security and income tax imposed on Palestinians working in Israel but still living in West Bank, (3) and the use of the Israeli currency in Palestine, also for import and export transactions, which is benefiting the Israeli economy. The estimated total of all these resources is found to be between $15 \%$ to $25 \%$ of the annual Palestinian GDP (Al-Naqib\&Attiyani, 2003).

Even so, the Palestinian economy was characterized by its growth during the period from 1994 to 2000 , as a result of the political stability achieved. The GDP increased at an annual rate of $11 \%$, and the increase rate was in Gaza Strip about $12.2 \%$ and $10.8 \%$ in the West Bank (Aqumassan, 2005).

\subsection{The second phase: $20002004-$ (Al-Aqsa Intifada)}

With the outbreak of Al-Aqsa Intifada in September 2000, the Palestinian economy started to face difficult conditions. On one side as a consequence of a complete isolation that was imposed on both Gaza Strip and the West Bank (not only in the circulation of people but also in imports and exports), as Israel proceeded to the closure of all external borders of the Palestinian territories, including those with Israel. Furthermore, the invasion of the West Bank in 2002 resulted in the destruction of many buildings and factories (in pretext of security reasons) and led to the set-up of Israeli 
checkpoints between towns and villages (World Bank, 2004). So, the decline in the industrial sector was inevitable, as those decisions created severe difficulties not only in the importation of raw materials from abroad through Israeli ports and borders, but also those decisions that cut the access to the foreign markets, and even brought huge difficulties in the access to the domestic market (a result of the checkpoints policy). Consequently, during the period correspondent with the Second Intifada, the number of industrial firms decreased from 11,509 in 2000 to 9,444 in 2004 (a decrease of $18 \%$ of the West Bank Industrial establishments); more than 2000 factories closed during this period of four years. This happened after a clear dynamic period of the first phase characterized by a growth in the number of factories, from 7185 in 1994 to 11509 in 2000, even if most of them were micro and small in terms of the number of workers (Al-Taibi, 2001).

This decreasing trend was accompanied by the declining in the total the number of workers in industrial activites, as after an increase from 32,173 in 1994 to 46,755 in 2000 (with an annual growth rate of 6,2\%). It was registered during the Al-Aqsa Intifada a decrease in the number of workers in the industrial sector, from 46755 in 2000 to 38487 in 2004 (Figure 5). During the Al-Aqsa Intifada employment rate in the industrial sector dropped significantly from $16.4 \%$ in 1999 to $12.7 \%$ in 2004 as a direct result of the Israeli imposed isolation of the West Bank. 


\section{مجلة جامعة الاستقلال للأبحاث المجلد (4) العدد (1) حزيران 2019}

Figure 5. The number of workers in the industrial sector in the West Bank during the period from 1994 to 2012

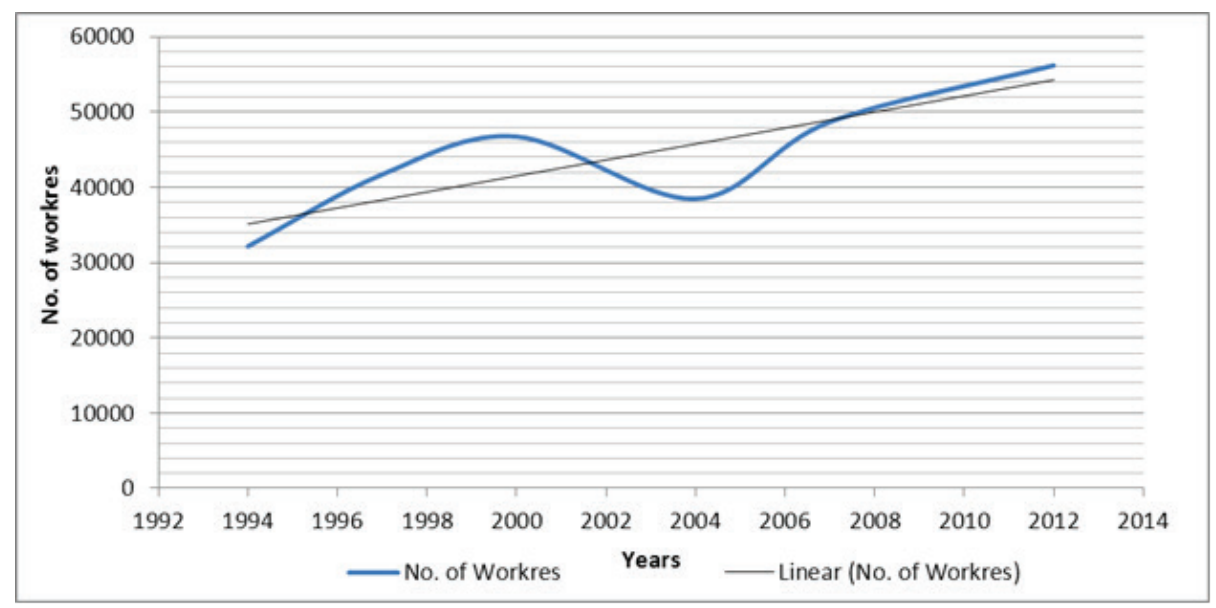

Source: data from PCBS (2000, 2013-b, 2015-a)

It is important to understand that according to PCBS (2000) the industrial employment increased in absolute values between 1994 and 2000, but not in relative values, as the employment rate in the industrial sector in 1995 was about $18 \%$ of the total number of Palestinian workers and decreased in 1999 to $16.4 \%$. As a result of the higher dynamism of the services activities in jobs creation and also a consequence of the higher wages in Israel which led to the attraction of many Palestinian workers during this phase (which started to became unavailable to join the West Bank firms labourforce). On the next phase this scenario has completely changed because Israel has stopped hiring labour force from the West Bank, and has imposed limitations on the Palestinians, who already worked in Israel and in the Israeli colonies, decreasing from $25,9 \%$ of the West Bank employees in 1999 to $10,7 \%$ in 2004 when Second Intifada ended PCBS $(2000,2006)$.

According to Alderaoi (2014) one of the reasons that help to explain why the industrial activity in the West Bank has clearly retracted during the Second Intifada, is in part related with the destruction, by offensive and devasting attacks, of more than $30 \%$ of the Palestinian factories during the Israeli 
invasion of 2002 , which has also caused partial damages on about $30 \%$ of the West Bank factories, causing the suspension (permanent or temporarily) of $60 \%$ of the Palestinian industrial activities. Other reasons presented by the author are related with the complete isolation of West Bank and Gaza Strip in order for Israel to prevent supplies, production inputs and machinery and equipment from arriving to the remaining Palestinian factories, as well as a way to hamper their exports. A decision that prevented West Bank firms from benefiting of the conquests achieved in the previous phase (1994-2000), namely the opportunities to explore external markets by exportations, or from the foreign investments attracted to the local economy. According to World Bank (2003) after two years of Intifada the levels of investment and trade were all significantly lower, as the total of investment has fallen from about 1.45 billion US\$ in 1999 to 150 million US\$ in 2002, a decline of about $90 \%$.

Besides the Palestinian per capita income felt by almost $40 \%$ during the first two years of the Second Intifada, which led to rising poverty and unemployment rate, which also contributed to explain the industrial activity retraction during the Second Intifada. The most affected industries were: food, textile, leather, and plastics industries. According to Kareem (2003), the West Bank industrial sector losses, from the beginning of the Second Intifada until the end of 2001, an amount around 540 million US dollars. About these losses, World Bank (2003) indicated that in the first two years of the Intifada, the Palestinian economy loss reached $7 \%$ of GDP, just from the effects caused in the industrial facilities that were operating before the attacks.

With regard to Palestinian industrial exports, statistics show a decline in the value of exports after 2000 compared with that of 1999 . The value of these exports dropped in 2001 by up to $37.3 \%$, and continued to decline in 2002 comparing with 1999 , by $22.6 \%$. The development of exports did not improve in 2003 , while in 2004 , there has been a relative improvement in the industrial export value compared to previous years, but it remained low by $19.9 \%$ in comparison to 1999 (PCBS, 2006). 


\subsection{The third phase: after 2005 (after Al-Aqsa Intifada)}

The Sharm el-Sheikn peace conference at 5th February 2005 sets the end of the Second Intifada (ILO, 2005), from this date started a new period, however,it's important to bear in mind that the Israeli military checkpoints in West Bank cities and borders have been kept. During this new phase, the number of factories increased again, from 9444 in 2004 to 12657 in 2012, reversing the downward trend of the previous phase (overcoming the total of industrial firms that were operating in the West Bank just before the AlAqsa Intifada: 11509 industrial units in 2000).

According to PCBS (2013-a), the most relevant industries in the West Bank in 2012, in number of firms, are 'metal products manufacturing, except machinery and equipment' with 2845 units, and 'wood and furniture manufacturing' with 2832 units. In global only these two activities are responsible for $44,9 \%$ of all manufacturing activities in the West Bank (Table 2 ), and the governorate that concentrates more of these two activities is Hebron, followed by Nablus. In the third position, it is ranked the activities related with the 'food and beverages manufacturing' with 2174 units, which corresponds to $17,2 \%$ of total West Bank factories. In this case the 2 governorates with more units are the same but in the inverse order, Nablus is the one that concentrate more of these manufacturing activities $(21,8 \%)$, followed by Hebron (16,3\%).

Only two more activities concentrate more than $10 \%$ of West Bank industrial units: the 'rubber and plastic products and other non-metallic products' with $14,2 \%$ and more concentrated in Hebron $(31,6 \%$ of them are located in Hebron), and the 'textiles and apparel manufacturing' with 12,4\% of all West Bank industries, and in this case, more concentrated in Nablus (26,7\% of these activities are located in Nablus). From a list of 11 different manufacturing activities, six concentrate less than $4 \%$ of the total West Bank industries (PCBS, 2013-a). 
Its possible to conclude that the structure of the West Bank manufacturing activities is not only characterized by its reduced diversity (just 3 in 11 groups of activities concentrated almost $2 / 3$ of all firms $-62,1 \%-)$, but also characterized by low tech activities with low added value. In fact, those activities with more knowledge intensity, present in countries with a more modern and qualified industry, are almost absent in this territory, as only $0,2 \%$ of West Bank industries are 'computer, electronics, optical and electric equipments products manufacturing', $1 \%$ are 'chemicals and basic pharmaceutical products', and even just $4 \%$ are 'manufacturing of machinery/equipments'.

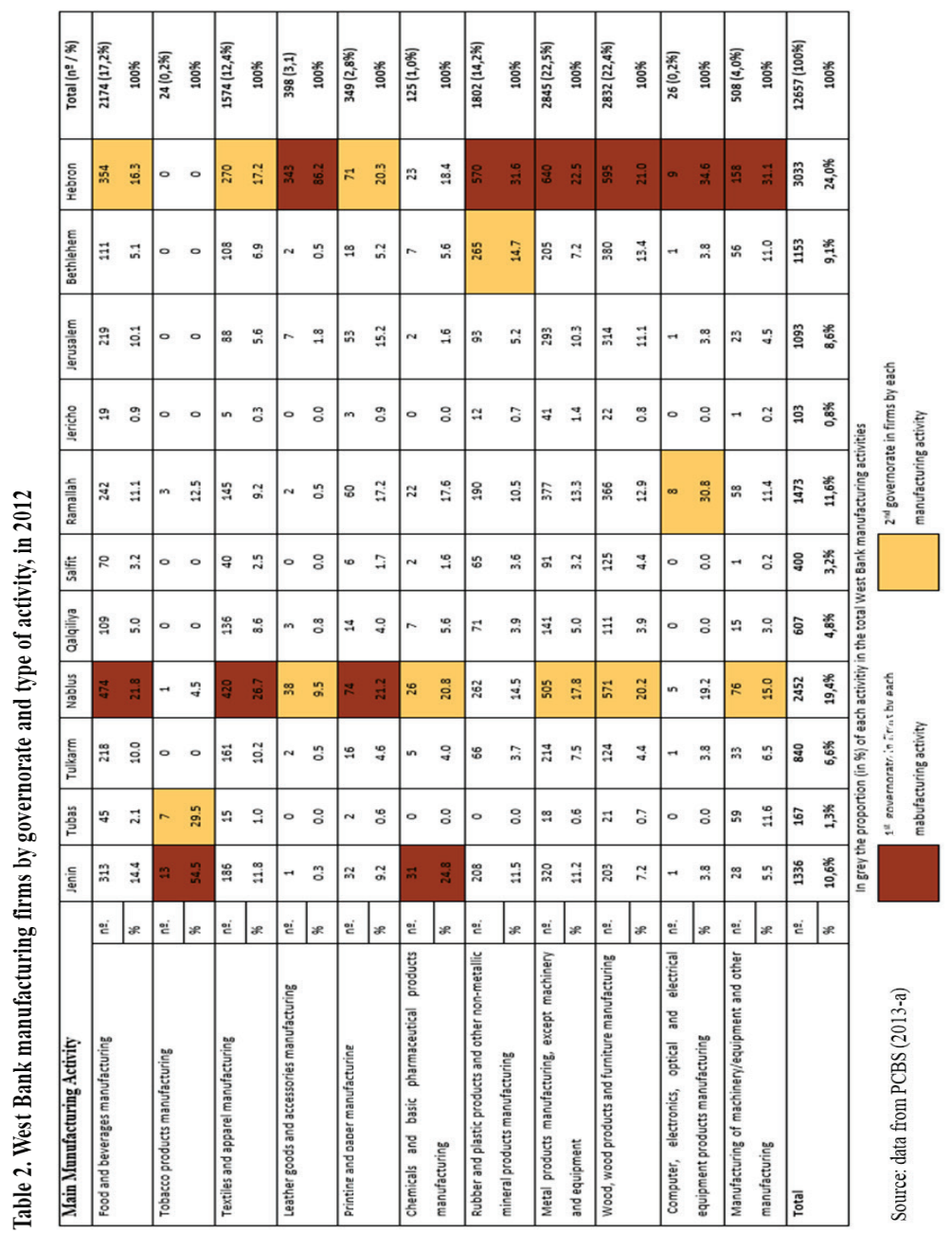


There is no available data about the absolute values of employment by governorate and manufacturing activity, so it is not possible to calculate the regional specialization indexes. Even so, and considering only the distribution of firms, it is possible to suggest the strongest regional specializations in the West Bank are in the 'leather goods and accessories manufacturing' with $86,2 \%$ of these activities located in just Hebron governorate, and also in the 'tobacco products manufacturing' with $54,5 \%$ in Jenin Governorate ( $84 \%$ considering Jenin and Tubas together, as they are neighbouring governorates).

In terms of its geographical distribution, the West Bank manufacturing activities were in 2012 mainly concentrated in Hebron in the south and Nablus in the north (Figure 6). The number of factories in Hebron reached 3033, which represents almost $1 / 4$ (24\%) of all West Bank industries. In Nablus governorate are located almost $1 / 5(19,4 \%)$ of the total of industries in the West Bank - 2452 units-, which represents a decrease in comparison with Nablus proportion in 1994 (26\%), but the reason to this decrease is the administrative amendments made by the Palestinian Authority in the midnineties of the last century which resulted in the separation of Salfit from Nablus governorate.

On the second level and still with more than 1000 industrial firms are four governorates: Ramallah \& Al-Bireh with 1473 units (11,6\%); Jenin with 1336 (10,6\%); Bethlehem with 1153 units (9,1\%) and Jerusalem with 1093 units $(8,6 \%)$. On the third level two governorates: Tulkarm with 840 units $(6,6 \%)$ and Qualqiliya with 607 (4,85). The governorates less industrialized are 3: Salfit with 400 units (3,2\%); Tubas with 167 units (1,3\%) and Jericho with 103 units $(0,8 \%)$. It is clear how the industrial activities are located in the governorates more populated and with the biggest cities, for reasons related with human resources proximity and access to the domestic market (this demographic effect is clear as the largest proportion of the population is located in Hebron). And the less populated governorates even if nearest from relevant markets in Israel (from cities as Tayibe, Netanya, Qalansawe, 
Hadera, Al-Ludd,Tel Aviv) or Jordanian (from cities as Al-Shounah,Salt, Jerash, Madaba) are not so interesting for the West Bank industrial entrepreneurs, which is a clear sign of the remarkable and intense border effect (Al-Ardda, 2000) in West Bank territory.

Figure 6. Geographical distribution of West Bank industrial firms, by governorate -2012

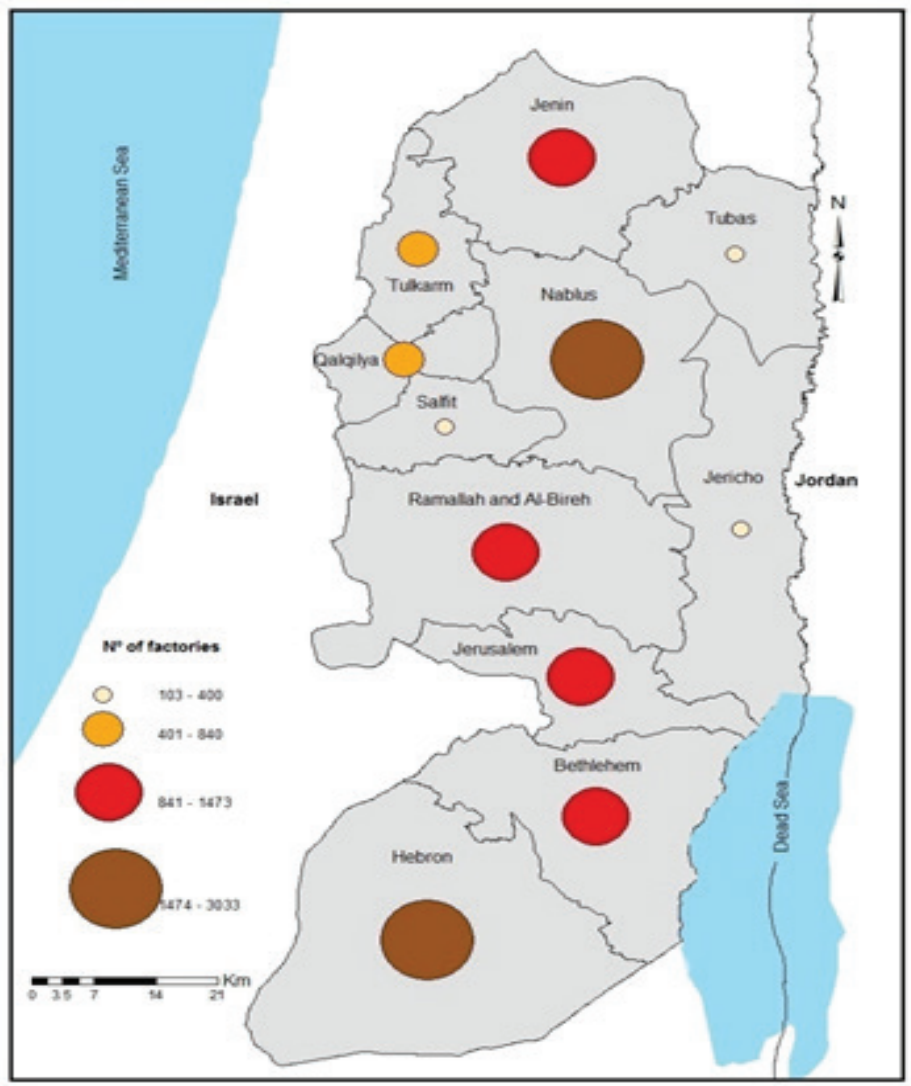

Source: author's elaboration with data from PCBS (2013-a)

The number of workers in the industrial sector has increased from 38,487 in 2004 to 56,213 in 2012, which represents a growth rate of $46 \%$ for a period of 8 years. In spite of the stabilization of the political situation in this phase and the growth in the industrial employment, it is important to realize that the huge growth rate of industrial workers is explained mainly because the 
absolute number of industrial workers was too low in 2004 as the industrial sector was seriously destroyed at the end of the Second Intifada. In fact, the absolute number of industrial workers have increases but the proportion of the industrial employment continue in a declining trend, from 12,7\% in 2004 to reach $10.4 \%$ in 2014 (PCBS, 2015-b). Palestinian workers were directed during these years mainly to the services activities, or to work in Israel and/or in the Israeli colonies, so, they were not available to be enrolled in the West Bank activities (the proportion of Palestinians working in Israel or Israelli colonies increased from $10.7 \%$ in 2004 to $16.1 \%$ in 2014) (PCBS, 2015-b).

It can be stated that the resurgence of the industrial sector during this phase (in number of factories and employment) has been not so dynamic as it was desired/needed to contribute to revitalize the West Bank economy. In fact, not only the proportion of employment in the industry has declined (even in spite the labour force is still an important production factor to the most common manufacturing activities in West Bank), but it also happened a decline in the percentage of the industrial sector contribution to the West Bank GDP and GVA (gross value added). According to PCBS (2015-b) the industrial sector contributed with 47\% for the Palestinian GDP in 2004 and dropped to reach $37.5 \%$ in 2014 , also the proportion of the industrial sector contribution in the gross value added decreased from $37.5 \%$ in 2004 to $25.9 \%$ in 2014.

Regarding the West Bank industry structure in terms of the firm's size, it is important to realize that according to the Palestinian Ministry of Industry definition (Council of Ministers - PNA, 2011), those factories with 1-4 employees are considered micro-sized, with 5-9 employees are considered small-sized, with 10-19 workers are considered medium-sized, while those with more than 20 workers are considered large-sized. So, there is a discrepancy between this definition and the one used in most developed countries, for instance in the European Union (EU) where a firm with 49 workers is considered a small sized firm (Surani, 2006), while in Palestine 
is considered a large sized firm, which makes it difficult to compare the statistics regarding their industrial activity structures.

According to PCBS (2013-a) the industrial sector in the West Bank is characterized by the clear dominance of micro-sized firms, as in 2012 more than $3 / 4$ of all factories employed only 1 to 4 workers. And if we also consider those with 59- workers (small sized) the proportion rises to $92 \%$. So, the West Bank industry structure is almost composed by small and micro-sized companies (in the EU definition those $92 \%$ of firms would be all considered micro enterprises, as micro enterprises in the EU are those with 1 to 9 employees). Less than 350 firms have more than 20 workers, so the large sized firms are just 2,7\% of all West Bank factories. Bethlehem is the West Bank governorate where it is observed a slightly higher proportion of larger firms, but even so a minority.

\section{Conclusion and Recommendations}

The First Intifada lasted for six years and ended with the signing of the Oslo Accords in 1993, a peace-treaty promoted by the United Nations, which created the political conditions to the establishment of the Palestinian Authority (Meckla, 2014). However, Israel continued to control and occupy the Palestinian lands and refused to discuss the nature and competences of the Palestinian Authority, the fate of Israeli colonies inside West Bank, the status of Jerusalem, the right of Palestinian refugees to return, the refugee's compensation and the water usage (Beinin, 1999). Years of peace talks have failed to produce any resolutions to these issues and in 2000 , the Second Intifada began, and as a result Israel built a long wall, which has isolated the West Bank. Palestinians became surrounded by the wall from all sides, moreover several Israeli checkpoints were created that cut off towns and villages in the West Bank in order to impose control directly on the ground, in terms of preventing movements of citizens and goods. Consequently, the wall and the checkpoints have been promoting the destruction of economic and social life in several ways, for instance, preventing the access of farmers to their lands; narrowing the ability to citizens to move, creating 
obstacles to the transport of raw materials and manufacturing goods as well as agricultural products.

So, almost 25 years after the establishment of the Palestinian Authority, the weakness of the West Bank industrial sector is in part a consequence of external forces, namely all the limitations imposed by Israel on the control of the Palestinian territory, previously discussed and summarized by Aburaida (2017). Between those it is possible to emphasize the negative consequences that came from the Palestinian Authority lack of control over its external and internal borders, namely obstacles in the raw materials importation (difficulties from high importation taxes for the use of Israel ports and harbours) or obstacles to sell West Bank goods in local and foreign markets (difficulties caused by the Israeli checkpoints as well as by the Standards Institution of Israel -SIl-which impose high standards specifications on the Palestinian products in order for them to be accepted in Israel or to be exported to the international markets). The continuous insecurity and political instability are other source of obstacles to local firms, as the achievements that resulted from the Oslo Accords did not end the local unstable context between Israel and Palestine, which affected negatively the West Bank economy. In fact, societies with a strong military presence by an external force are societies with a future uncertain and ambiguous, less trustful and consequently less attractive to investments (domestic and foreigners).Unfair competition affecting West Bank goods is also a main obstacle to local firms, which was mainly caused by the Paris Economic Protocol that gave the opportunity for the Israeli products to invade the Palestinian market at the same time it prevents the Palestinian products from entering the Israeli market. Finally, and still about obstacles originated by the influence of the Israel occupation, it is important to mention some adversities and limitations in the use of local infrastructures. West Bank firms face several difficulties in the use of local infrastructures, which is specially felt in two domains: roads accessibility; and supplying infrastructures (access to water or electricity). 
The negative influence of those obstacles was not constant over these almost 25 years, a period where globally the Palestinian economy has become less diversified, and clearly based at the service sectors, as a consequence of an employment decrease in the primary and secondary sectors. Immediately after the Oslo Accords the most relevant manufacturing activities were concentrated in Nablus governorate and were related with metal products, food industry and clothing/textiles goods. During this first phase the industrial sector has witnessed a rapid development in the West Bank, as a consequence of several plans, programs and laws set up by the Palestinian Authority. As a result of all those policies, the industrial sector's contribution to GDP(gross domestic product) increased from $8 \%$ in 1993 to $16.8 \%$ in 1998. Moreover, according to PCBS (2000) the industrial employment increased in absolute values between 1994 and 2000. However, and despite the positive evolution of this first phase, some constraints avoid a better performance of the West Bank industrial sector, namely the high dependence of the local market and the difficulties to conquest external markets (MAS, 2001), which is mostly a consequence of the 'Paris Economic Protocol' signed in 1994, that created an unfair competition for the West Bank goods. Paris Economic Protocol gave the opportunity for the Israeli products to invade the Palestinian market at the same time it prevented many of the Palestinian products from entering the Israeli market. Besides, the Paris Economic Protocol increased raw material prices with higher customs on raw materials imported from Israel and from other countries, which had a negative impact on the local industrial competitiveness.

With the outbreak of Al-Aqsa Intifada in September 2000, the West Bank industry started to face more difficult conditions in selling their products in foreign markets (a complete isolation was imposed by Israel to West Bank and Gaza Strip) but also in the domestic market (consequence of the Israeli checkpoints between towns and villages). Furthermore, the invasion of the West Bank in 2002 resulted in the destruction of many factories (in pretext of security reasons). It was observed the destruction, by offensive 
and devasting attacks, of more than $30 \%$ of the Palestinian factories during the Israeli invasion of 2002, which has also caused partial damages on about $30 \%$ of the West Bank factories, causing the suspension (permanent or temporarily) of $60 \%$ of the Palestinian industrial activities.Consequently, during the period correspondent with the Second Intifada, the number of industrial firms decreased from 11,509 in 2000 to 9,444 in 2004.This decreasing trend was accompanied by the declining in the total the number of workers in industrial activities, as it was registered during the Al-Aqsa Intifada a decrease in the number of workers in the industrial sector, from 46755 in 2000 to 38487 in 2004. Moreover, World Bank (2003) indicated that in the first two years of the Intifada, the Palestinian economy loss reached $7 \%$ of GDP, just from the effects caused in the industrial facilities that were operating before the attacks.

After the end of Second Intifada, the number of industrial factories increased again, from 9444 in 2004 to 12657 in 2012, reversing the downward trend of the previous phase. In terms of its geographical distribution, the West Bank manufacturing activities is now mainly concentrated in Hebron in the south, where the number of factories reached 3033, which represents almost $1 / 4$ (24\%) of all West Bank industries.In spite of the stabilization of the political situation in this phase and the growth of the industrial employment, it is important to realize that the proportion of the industrial employment continue in a declining trend, from $12,7 \%$ in 2004 to reach $10.4 \%$ in 2014 (PCBS, 2015-b). It was also observed a decline in the percentage of the industrial sector contribution to the West Bank GDP and GVA (gross value added). According to PCBS (2015-b) the industrial sector contributed with 47\% for the Palestinian GDP in 2004 and dropped to reach $37.5 \%$ in 2014. So, it can be stated that the resurgence of the industrial sector during this third phase has been not so dynamic as it was desired/needed to contribute to revitalize the West Bank economy. This trend is above all a consequence of all limitations imposed by Israel to the West Bank industry, despite the Oslo Accords, namely all those that created an unfair competition to the 
West Bank goods. In terms of recommendations it is important to emphasize that this unique and specific occupation framework and all the obstacles it brings to the West Bank industry, justifies the debate about the pertinence of some protectionist measures to be taken the Palestinian Authority to preserve and reinforce the competitiveness of West Bank industrial goods, such as:

1. Encourage local investments (including small projects) through tax exemptions, loans and financial facilities, which will reflect on the quality of products and will make them capable of competing with the products of the Israeli colonies, as well as foreign goods;

2. Impose higher tariffs on imported goods and a better control of the products that enter the Palestinian markets (especially the ones that are locally available), in order to protect the local production;

3. Revise the Paris Economic Protocol, under the supervision of UN economists, and establish economic relations with Israel on a new basis, for instance based on political negotiations with Israel aiming the creation of a common joint 'domestic' market integrating both Israel and West Bank, to be an open market explored simultaneously and in a fair way by Israeli and West Bank firms.;

4. Restore the consumer confidence in local products and reinforce the awareness of the West Bank community for the importance of buying Palestinian products, with a communication strategy that could involve several methods as advertising measures (including social media);

5. Reinforce the commitment with the campaign of boycott to Israeli colonies goods, systematically in all governorates, activating deterrent laws against the suppliers and importers of the Israeli colonies goods. 


\section{REFERENCES}

- Abdul-Karim, N. (2004). General background on the economic and social situation in the Palestinian territories. The current Palestinian economic situation and development opportunities. Ramallah: PLO Palestine's Liberation Organisation.

- Abdul-Khaliq, N. (2004). Analysis The Functions Of Production And Productivity In The Palestinian Industry. Nablus: An-Najah National University.

- Abu Hawa, I. (2014). Employment In The West Bank To Ramallah. Aliqtisadi.

- http://www .Aliqtisadi. Ps /Ar_Print.Php?ld=3d4b8y251064y3d4b8. [accessed on July 12, 2016]

- Aburaida, L. (2017). Main challenges faced by the Palestinian industry in the West Bank. Braga: Universidade do Minho.

- Al-Ardda, N. (2000). Palestinian Jordanian Foreign Trade And Reality And Future Prospects. Ramallah: Palestine Economic Policy Research Institute-MAS.

- Al-Naqib, F. and Attiyani, N. (2003). The reality and the future of IsraeliPalestinian economic relations. Ramallah: Palestine Economic Policy Research Institute-MAS. (In Arabic)

- Al-Sayeh, A. (2015). From Palestine land: Palestinian Plant Agricultural Production In The West Bank Between Opportunities And Risks And Obstacles.

- http://www.Palestineland.Net/Index.Php/Content-Catego ry-2/1056-2015-11-05-18-21-14. [accessed on November 23, 2015] (In Arabic)

- Al-Taibi, A. (2001). Analysis And Measurement Worker Productivity In Manufacturing In The West Bank. Nablus: An-Najah National University. 
(In Arabic)

- Alderaoi, S. (2014). Factors Affecting the Development of Palestine Economic Relations in the Light of Regional and International Changes: Prospectives. Journal of the University of Palestine Research and Studies, $\mathrm{N}^{\circ} .6$, pp. $285-416$.

- Aqumassan, K. (2005). An Analytical Study Of The Reality Of The Palestinian Economy Between Investment Opportunities And Challenges Of The Future. Investment And Financing In Palestine Between Development Prospects And Contemporary Challenges. Gaza: Islamic University.

- ARIJ (2015). Localities Study And Needs In Jerusalem Governorate. Jerusalem: ARIJ - Applied Research Institute Jerusalem. (In Arabic)

- Attiyani, N. (2016). Palestinian industrial sector reality contrary ambition.

- http://www.palestineeconomy.ps/article/5780/. [accessed on March 23, 2016]

- Beinin, J. (1999). The demise of the Oslo process. Washington: Merip.

- Council of Ministers - PNA (2011). The Ratification Of The Definition And Classification Of Economic Establishments Micro, Small, Medium And Large. Cabinet Decision No.(1/105/13). Ramallah: Council Of Ministers - Palestinian National Authority. (In Arabic)

- El-Jafari, M (2016). Prospects and Potential for Enhancing the Palestinian Business and Trade Environment. Towards a New Vision for the Revival of the Palestinian Economy. MAS Economic Conference 2016 - Ramallah.

- Epstein, Y. (2002). The Palestinian Labor Market in Israel: Between Globalization and Intifada. Palestine-Israel Journal of Politics, Economics, and Culture, 8(4), 149. 
- Hazboun, S. and Bahiri, S. (1994). Palestinian Industrial Development and Israeli-Palestinian Attitudes to Cooperation. Palestine-Israel Journal, Vol.1, No.4 , p. 5.

- ILO (2005). The situation of workers of the occupied Arab territories. Geneva: International Labour Office.

- Kareem, N. (2003). An evaluation study of the impact of the economic development policies of the Palestinian National Authority the right to work during the transitional phase. Ramallah: The Center for Democracy and Workers' Rights.

- Makhol, B. and Atyani, N. (2001). Critical Review Of The Proposes Palestinian Industial Law. Ramallah: Palestine Economic Policy Research Institute (MAS).

- MAS (2001). Economic Observer Issue Nº 8. Ramallah: Palestine Economic Policy Research Institute (MAS).

- MAS (2012). Round Table Discussion (7): Recent Amendments To Trade Arrangements In Paris Protocol. Ramallah: MAS - Palestine Economic Policy Research Institute.

- MAS (2013). The Palestinian Economy After 20 years of Oslo Accords, Final Report Round Table Discussion (9). Ramallah: MAS - Palestine Economic Policy Research Institute.

- Meckla, M. (2014). Palestine and the Arab-Israeli Conflict: A History with Documents. The European Legacy: Toward New Paradigms, Vol. 19. N. 3, pp. 398-399.

- Naqib, F. M. (2003). Economic aspects of the Palestinian - Israeli conflict: the collapse of the Oslo Accord. Journal of International Development, 15(4), 499-512.

- Nasrallah, A. and Awad, T. (2004). The Reality Of The Industrial Sector In Palestine. Ramallah: Ministry of National Economy. 
- http://www.mne.gov.ps/studies.aspx?lng=2\&tabindex $=100 \& \mathrm{~m} \quad=0$ [accessed on October 5, 2016] (In Arabic)

- PALTRADE (2016). International Trade Agreements. Ramallah: PALTRADE - Palestine Trade Center.

- PCBS (1996). The Industrial Survey - 1994: Main Results. Report № 2 (Governorates Results). Ramallah: Palestinian Central Bureau of Statistics.

- PCBS (1997). Labour Force Survey: Annual Report: 1996. Ramallah: Palestinian Central Bureau of Statistics

- PCBS (2000). Labour Force Survey: Annual Report: 1999. Ramallah: Palestinian Central Bureau of Statistics.

- PCBS (2006). Comparison Study On The Industrial Activities, 19992004. Ramallah: Palestinian Central Bureau Of Statistics.

- PCBS (2013-a). Establishments Census 2012 - Main findings. Ramallah: Palestinian Central Bureau of Statistics.

- PCBS (2013-b). The labor force survey ,Labor force Data Base 2012. Ramallah: Palestinian Central Bureau of Statistics.

- PCBS (2015-a). Labour Force Survey. Annual Report: 2014. Ramallah: Palestinian Central Bureau of Statistics.

- PCBS (2015-b). Economic Surveys Series 2004, 2006, 2014. Ramallah: Palestinian Central Bureau of Statistics.

- PCBS (2016).Labour Force Survey: Annual Report: 2015. Ramallah: Palestinian Central Bureau of Statistics.

- PCHR (2016). Weekly Report On Israeli Human Rights Violations in the Occupied Palestinian Territory (17 - 24 November 2016), Ramallah: Palestinian Center for Human Rights.

- PFI-USAID (2009). The Current Status of the Industrial Sector in Palestine Outlook Based on Indicators. Ramallah: PFI - Palestinian 
Federation of Industries \& USAID - United States agency International Development.

- PIEFZA (2014). The Palestinian Industrial Estates And Free Zones Authority. http://www.Piefza.Ps/En/Content/Oss. [accessed on October 19, 2016]

- PIEFZA (2015). The Palestinian Industrial Estates And Free Zones Authority. Annual Report 2015.

- http://Www.Piefza.Ps/En/Content/Publications. [accessed on July 9, 2016]

- PIPA (1998). The Palestinian Investment Promotion Agency.

- http://Www.Ipa.Ps/. [accessed on November 12, 2015]

- Meckla, M. (2014). "Palestine and the Arab-Israeli Conflict: A History with Documents". The European Legacy: Toward New Paradigms, Vol. 19. N. 3, pp. 398-399.

- Rantisi, H. (2016). The Palestinian Industrial Sector: a Reality that Falls Short of Ambition. Ramallah: Palestine Economy Portal - Palestinian Economic Council for Development \& Reconstruction.

- Shu'aybi, H. (2013). Paris Protocol, Reality reviewen and forcement. Bethlehem: Palestine Economic Policy Research Institute (MAS).

- Surani, G. (2006). The reality of industry and trade in the West Bank and Gaza Strip. Ramallah: The Ministry of Economy.

- UN-DESA (2013). World Economic And Social Survey 2013: Sustainable Development Challenges. New York: United Nations - Department Of Economic And Social Affairs.

- UNCTAD (2011). The Rebuilding Of Palestinian Goods Trade Sector: Towards The Economic Recovery And The Creation Of The State Formation. New York: UNCTAD - United Nations Conference on Trade and Development. 
- World Bank, (2003). After two years of the intifada and the siege and closures and Palestinian economic crisis. Ramallah: World Bank.

- World Bank, (2004). Four Years - Intifada, Closures And Palestinian Economic Crisis. Ramallah: World Bank.

- World Bank (2013). West Bank And Gaza Strip: Area C And The Future Of The Palestinian Economy. Report No. Aus 2922. Ramallah: World Bank. 